\title{
INFLUENCE OF FERTILIZATION ON MICROBIAL ACTIVITIES, SOIL HYDROPHOBICITY AND MINERAL NITROGEN LEACHING
}

\author{
WPLYW NAWOŻENIA NA AKTYWNOŚĆ MIKROORGANIZMÓW, \\ HYDROFOBOWOŚĆ GLEBY ORAZ WYPLUKIWANIE AZOTU MINERALNEGO
}

\begin{abstract}
This work presents the analysis of the influence of compost and reclamation substrate addition and mineral fertilizers application on leaching of mineral nitrogen, microbial activities, soil hydrophobicity and plant biomass production. To demonstrate the effect of compost, reclamation substrate and mineral nitrogen $\left(\mathrm{N}_{\min }\right)$ addition on above parameters, the pot experiment was performed. As a model crop, Deschampsia caespitosa L. was used and cultivated for 63 days in climate chamber. The leaching of $\mathrm{N}_{\min }$ was measured by application of ion exchange discs, soil hydrophobicity was determined based on the values of saturated hydraulic conductivity $\left(K_{\text {sat }}\right)$ and microbial activity was expressed as basal $(B R)$ and substrate induced respiration (SIR). Four variants (V1-V4) with different doses of fertilizers were prepared: V1 - control without addition of fertilizers; V2 - this variant of experiment was prepared as mixture of compost and arable land in ratio 7:3; $\mathrm{V} 3-90 \mathrm{~g} / \mathrm{m}^{2}$ of mineral fertilizers NPK (in the ratio 1:1:1) were applied there and into V4, dose $30 \mathrm{~g}$ of compost were applied. The significant differences $(P<0.05)$ in the detection of $\mathrm{N}_{\min }$, values of $K_{\text {sat }}$ and $S I R$ were found. The highest decrease of mineral nitrogen leaching was observed by the simultaneous applications of compost (V4) to arable soil, about $50 \%$ in comparison with the variant V4 (application of mineral fertilization) and about $10 \%$ in comparison with the control. Variants with addition of compost (V2 and V4) showed higher values than variants without, which were measured at three stages (before application of $\mathrm{N}_{\min }-12$ days after establishment of the experiment; after application of $\mathrm{N}_{\min }$ - 34 days; at end of the experiment - 63 days). During the experiment, two types of respiration were measured: $B R$ and SIR. The significant differences in SIR were found between variants with addition of compost and variants without. The SIR (cumulative production of $\mathrm{CO}_{2}$ ) was higher about $25 \%$ in variants V2 and V4 compared to variants V1 and V3. The highest values of $K_{\text {sat }}$ were found in variants with addition of compost. Conversely, the lowest value of $K_{s a t}$ was detected in variant with addition of $\mathrm{N}_{\min }$. Low values of $K_{\text {sat }}$ indicate an increased level of hydrophobicity.
\end{abstract}

Keywords: compost, reclamation substrate, microbial activity, mineral nitrogen, soil hydrophobicity

\footnotetext{
${ }^{1}$ Department of Agrochemistry, Soil Science, Microbiology and Plant Nutrition, Faculty of Agronomy, Mendel University in Brno, Zemědělská 1, 61300 Brno, Czech Republic, phone +420 545132484

${ }^{2}$ Department of Applied and Landscape Ecology, Faculty of Agronomy, Mendel University in Brno, Zemědělská 1, 61300 Brno, Czech Republic, phone +420 545132484

*Corresponding author: magda.vaverkova@uake.cz
} 


\section{Introduction}

Soil is a natural resource that is not renewable in a historical time scale. Soil is the first link in the food chain determines the chemical composition of plants, and finally the health of humans and animals [1]. Soil erosion is a natural phenomenon and has occurred throughout geological history. However, human activities have increased erosion rates. This human influenced process is termed accelerated erosion [2]. Erosion is a major factor for soil degradation which causes irreversible effects.

Today in many parts of Eastern Europe the soil cover was significantly damaged by erosion processes [2]. Significant erosion influence on soil cover due to human impact started in medieval times [3]. Soil erosion, leaching of nutrients and soil fertility depletion are one of the key threats to soil in both industrialized countries (developed) and in developing countries. These problems include increasing application of mineral fertilizers, decrease in addition of organic materials such as manure or organic waste compost into arable land and cultivation on marginal and fragile lands [4-6].

Soil has been perceived by human beings as a source of building materials and as the medium for farming, ergo the lowest component of the food chain. However, from an environmental point of view, soil should be perceived as an ecosystem, the quality of which is influenced positively or negatively by the mutual interaction of individual (animate and inanimate) components. For that reason, soil has to be considered an animate, dynamic and vitally important part of the ecosystem [7].

Within an environmental and sustainable agricultural policy, reduction of soil erosion must be a priority. Erosion causes damage not only to cultivated soils, but it also affects water quality and is responsible for sediment transport, causing many off-site problems such as mud floods. Hereafter, we only consider water erosion occurring in cultivated areas, excluding erosion of river banks and mountain areas, as well as mass movements that result from different factors and processes [8].

Currently modern agriculture is faced with the question of how to resolve these issues. These problems can be solved only by changes in the farming. The basis of all changes in modern (intensive) agriculture should be to achieve sustainable arable soil. Sustainable arable soil is the cornerstone of sustainable agriculture. This new way of agricultural management represents a different approach to farming on arable soil. Sustainable agriculture aims to increase soil organic matter content, support microbial activity and improve soil physical a chemical parameters [9].

The fundamental change is to increase the content of soil organic matter in arable soil using organic substances. Organic matter (substances) can be applied as manure, crop residues, compost or reclamation substrates that are suitable for highly degraded soil $[4,5]$.

A significant problem is the price of these materials and their application. For example, the decline in livestock production and the cultivation of monoculture instead of forage in the Czech Republic is the main reason for the lack of organic residues; these are necessary to increase the content of soil organic matter in the Czech Republic. Thus, in the second half of the nineties farmers started to look for compensation and found it in the form of a compost.

Compost, the main product of composting, may be defined as the stabilized and sanitized product of organic matter decomposition [9]. Czech farmers' lack of interest to use compost as organic fertilizer caused that the compost producers can start to use more for 
the preparation of reclamation substrates [10]. Application of compost (from vegetable, fruit, garden and organic waste) and reclamation substrate that is made from it has positive influence on soil fertility, soil properties (chemical and physical) and microbial activity [9, 11]. This positive influence is possible due to the chemical composition and structure of the compost. More than $80 \%$ of the total nitrogen content is in organic compounds together with carbon. Available carbon and nitrogen is source of energy for microorganisms, thus this energy can be subsequently used for the processing of nitrogen. Consequently, nitrogen is fixed in the bodies of soil microorganisms and during their life cycle nitrogen is progressively released into the rhizosphere of cultivated crops. Positive influence of compost on soil structure is based on the content of the solid fraction $(>5 \mathrm{~mm})$, which in combination with organic substances makes a prerequisite for increasing the ability of water retention and creation of capillary pores [4, 5, 9]. These facts are very important for achieving the optimum soil properties and thus cost-effective production of cultivated crops.

Therefore, the influence of compost and reclamation substrate addition as well as mineral fertilizer addition on selected parameters was studied. The hypothesis arguing that the compost addition has better positive effect on plant growth, microbial activities, the leaching of mineral nitrogen from arable soil and soil hydrophobicity than the reclamation substrate addition and mineral fertilizer application was tested. This paper presents the results of a laboratory experiment.

Objectives of this study were: (i) to determine and compare the effect of compost, reclamation substrate and mineral nitrogen addition on microbial activity; (ii) to determine and compare the effect of compost, reclamation substrate and mineral nitrogen addition on soil hydrophobicity and leaching of mineral nitrogen from arable soil; (iii) to identify the influence of the above fertilizing substances on soil fertility - production of plant biomass.

\section{Material and methods}

The experiment was carried out in plastic experimental containers (Fig. 1) of a diameter of $10 \mathrm{~cm}$ and a height of $11 \mathrm{~cm}$ filled up with arable soil collected from protection zone of underground drinking water source Březová nad Svitavou, where annual climatic averages (1962-2012) are $588.47 \mathrm{~mm}$ of precipitation and $7.9^{\circ} \mathrm{C}$ mean annual air temperature.

Each experimental container was filed with $550 \mathrm{~g}$ of arable soil (with or without the addition of compost and mineral fertilizer). Soil sampling was carried out on $25^{\text {th }}$ November 2013 in accordance with the Czech National Standard CSN ISO 10 381-6. Compost $\left(\mathrm{C}_{\mathrm{p}}\right)$ was obtained from the Central Composting Plant in Brno. Samples of $\mathrm{C}_{\mathrm{p}}$ were taken on $27^{\text {th }}$ November 2013 in accordance with the Czech National Standard CSN EN 465735. Samples were sieved (grid size of $2 \mathrm{~mm}$ ) and stored in a thermostat at a temperature of $4{ }^{\circ} \mathrm{C}$. The experimental containers were filed with soil samples on $25^{\text {th }}$ February 2014. Deschampsia caespitosa was used as a model plant to determine the effect of compost, reclamation substrate addition and the application of mineral nitrogen on plant production. Individual plants (seedlings) for the experiment were pre-cultivated from a formerly single clump of grass. Pre-cultivated seedlings were kept for one month. Before transplanting, both aboveground and underground parts of seedlings were reduced to the same size. 


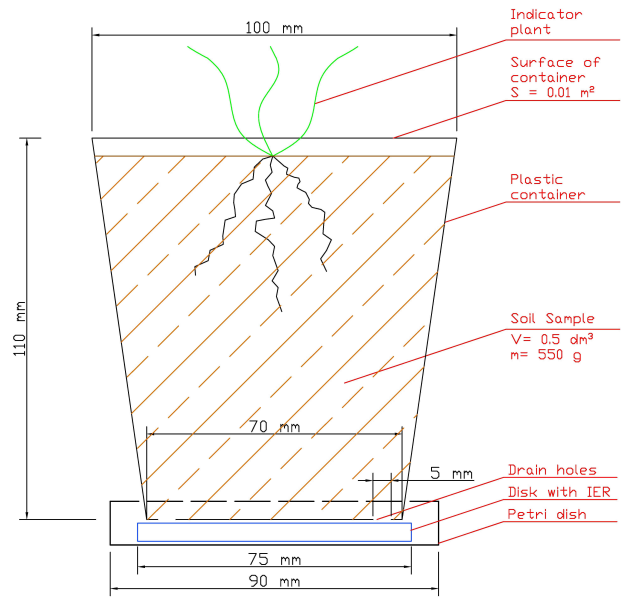

Fig. 1. Experimental container

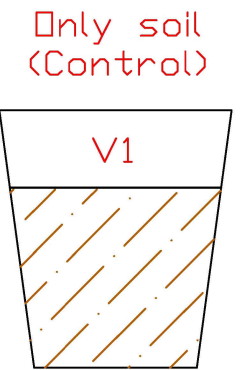

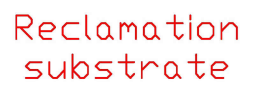

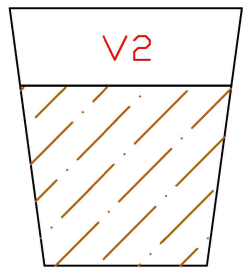

$100 \%$

NPK

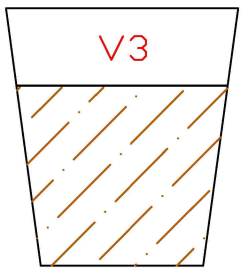

$100 \%$ Compost

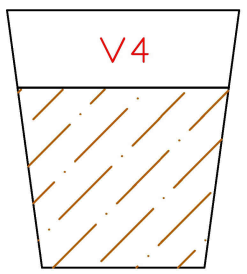

Fig. 2. Distribution of laboratory experiment (percentages represent the proportion of the applied recommended dose of NPK and compost; precise doses of fertilizers are listed above)

The experiment was conducted in the period from $25^{\text {th }}$ February to $28^{\text {th }}$ April 2014 (63 days). During the whole experiment, plants were kept in a climate chamber at $22^{\circ} \mathrm{C}$ with a day length of 16 hours and a light intensity of $300 \mu \mathrm{mol} / \mathrm{m} \cdot \mathrm{s}$.

Four variants (V1-V4) of the experiment with different doses of fertilizers $\left(\mathrm{C}_{\mathrm{p}}\right.$, RS and GSH) were prepared. All used fertilizers are registered for agriculture use in the Czech Republic (under Fertilizers Law). GSH (mineral fertilizer containing N, P, K and S in the ratio 10:10:10:13) and special type of $C_{p}$ - Black Dragon (BD) were used, because these types are registered by Ministry of Agriculture - Central Institute for Supervising and Testing in Agriculture (GSH-NPK reg. no: 2007 and $\mathrm{C}_{\mathrm{p}}$ reg. no.: 3372). Each variant had four repetitions: V1 - control was conducted without the addition of fertilizers. V2 - this variant of the experiment (reclamation substrate) was prepared as a mixture of compost and arable soil in ratio 7:3. As for variant V3, only mineral fertilizer was used (GSH). One hundred percent of recommended dose of mineral fertilizer was applied here $\left(90 \mathrm{mg} \cdot \mathrm{m}^{-2}\right.$ of GSH). Within variant V4 a $30 \mathrm{~g}$ dose of compost was applied (recommended dose in accordance with the Czech National Standard ČSN EN $465735-50 \mathrm{Mg} \cdot \mathrm{ha}^{-1}$ ). This dose represents one hundred percent of recommended dose of compost. 


\section{Measurement of leached mineral nitrogen}

Mineral nitrogen $\left(\mathrm{N}_{\min }=\mathrm{NH}_{4}{ }^{+}-\mathrm{N}\right.$ and $\left.\mathrm{NO}_{3}{ }^{-}-\mathrm{N}\right)$ that leached from the experimental containers was captured by special discs with mixed IER (Ion Exchange Resin). Discs were located under each experimental container. The discs were made from plastic (PVC) tubes. Each disc was $75 \mathrm{~mm}$ in diameter and $5 \mathrm{~mm}$ thick. From both sides of each disc, nylon mesh was glued (grid size of $0.1 \mathrm{~mm}$ ). Mixed IER (CER - Cation Exchange Resin and AER - Anion Exchange Resin in ratio 1:1) were then placed into the inner space of annular flat cover [12].

After the termination of the Ion Exchange Resin experiment, quantification of $\mathrm{N}_{\text {min }}$ trapped by the mixed IER (resin) was performed. At first the disks were dried at laboratory temperature $\left(18.5^{\circ} \mathrm{C}\right)$ for one week. After 7 days dry IERs were removed from individual discs and divided by the variants (V1, V2, V3, and V4). Subsequently, captured $\mathrm{N}_{\min }$ was extracted from IER using $100 \mathrm{~cm}^{3}$ of $1.7 \mathrm{M} \mathrm{NaCl} . \mathrm{N}_{\min }$ that was released by $\mathrm{NaCl}$ was determined by distillation-titration method according to Peoples et al [13]. The value of $\mathrm{N}_{\min }$ was calculated as the sum of the detected ammonium and nitrate forms. The results obtained from the analyses of IER were expressed in $\mathrm{mg}$ of $\mathrm{N}_{\min }$ per $\mathrm{m}^{2}$ (surface of experimental containers $-\mathrm{mg} \cdot \mathrm{m}^{-2}$ ).

\section{Index of nitrogen availability - ammonium production during waterlogged incubation}

Ammonium production during waterlogged incubation was used to determine the amount of $\mathrm{N}$ which was stored in the microbial biomass. In this method that was carried out by Bundy \& Meisinger [14], soil $\mathrm{N}$ availability is estimated from $\mathrm{NH}_{4}{ }^{+}-\mathrm{N}$ produced during a seven-day waterlogged incubation. The method is based on the determination of difference between the original and final content of $\mathrm{NH}_{4}{ }^{+}-\mathrm{N}$. This difference is appropriate to the amount of nitrogen that was previously stored in the original microbial biomass before the incubation. The only anaerobic as well as facultative anaerobic thermopiles (these bacteria constitute a minority in the original soil environment) can survive these extreme conditions of waterlogged incubation at $40^{\circ} \mathrm{C}$. Organic $\mathrm{N}$ from original microorganisms is mineralized during the incubation and accumulated as $\mathrm{NH}_{4}{ }^{+} \mathrm{N}[12,14]$. The method of nitrogen availability index consists of two parts.

The first part (A) is used to determine the content of $\mathrm{NH}_{4}{ }^{+}-\mathrm{N}$ and $\mathrm{NO}_{3}{ }^{-} \mathrm{N}$ before incubation. $\mathrm{NO}_{3}{ }^{-} \mathrm{N}$ is determined to find out how many $\mathrm{N}_{\min }$ was in soil. This parameter is very important in evaluating the amount of $\mathrm{N}_{\min }$ that escaped from the soil. The second part (B) is used to determine the content of $\mathrm{NH}_{4}{ }^{+}-\mathrm{N}$, which is floated out of the microbial cell. In part A $20 \mathrm{~g}$ of soil sample (from each variant and repetition) and $100 \mathrm{~cm}^{3}$ of $2 \mathrm{M} \mathrm{KCl}$ (two molar solution of potassium chloride) were placed into incubation bottle and shaken for 60 min. After shaking, suspension was filtered and concentration of $\mathrm{NH}_{4}{ }^{+}-\mathrm{N}$ and $\mathrm{NO}_{3}{ }^{-}-\mathrm{N}$ was performed by distillation-titration method according to Peoples et al [13]. In the second part (B) $20 \mathrm{~g}$ of soil sample (from each variant and repetition) and $50 \mathrm{~cm}^{3}$ of distilled water were placed into incubation bottle. After $7^{\text {th }}$ day of incubation at $40^{\circ} \mathrm{C}, 50 \mathrm{~cm}^{3}$ of $4 \mathrm{M} \mathrm{KCl}$ were added and the sample was shaken for $60 \mathrm{~min}$. After shaking, suspension was filtered and concentration of $\mathrm{NH}_{4}{ }^{+}-\mathrm{N}$ was performed according to the same method as before the incubation [12, 14]. 
The results obtained from the determination of mineral nitrogen $\left(\mathrm{NH}_{4}{ }^{+}-\mathrm{N}\right.$ and $\mathrm{NO}_{3}{ }^{-} \mathrm{N}$ before incubation) and ammonia nitrogen (after incubation) were expressed in $\mathrm{mg}$ of $\mathrm{N}_{\text {min }}$ per $\mathrm{kg}$ and in $\mathrm{mg}$ of $\mathrm{NH}_{4}{ }^{+}-\mathrm{N}$ per $\mathrm{kg}$ of soil.

\section{Determination of basal and substrate induced respiration}

Basal respiration (BR) was determined by measuring the $\mathrm{CO}_{2}$ production from soils incubated in serum bottles for 24 hours. Field moist soil $(15 \mathrm{~g})$ was weighed into each of three $120 \mathrm{~cm}^{3}$ serum bottles. Bottles were sealed with butyl rubber stoppers and incubated at $25^{\circ} \mathrm{C}$. After 3 and 24 hours a $0.5 \mathrm{~cm}^{3}$ sample of the internal atmosphere in each bottle was analyzed by gas chromatography (Agilent Technologies 7890A GC System equipped with a thermal conductivity detector). Respiration was calculated from the increase in $\mathrm{CO}_{2}$ during the $21 \mathrm{~h}$ incubation period. At the end of the measurements, the total headspace volume for each replicate bottle was determined by measuring the volume of water required to fill the bottle. The measured amounts of $\mathrm{CO}_{2}$ were corrected for the gas is solved in the liquid phase. The results are expressed per gram of dry soil and hour [15].

Substrate induced respiration (SIR) was determined by measuring the $\mathrm{CO}_{2}$ production from soils incubated in serum bottles for 4 hours after the addition of glucose. Field-moist soil $(5 \mathrm{~g})$ was added to three replicate serum bottles as described for the determination of BR in the previous paragraph, and $2 \mathrm{~cm}^{3}$ of a glucose solution was added to each bottle ( $4 \mathrm{mg} \mathrm{C} / \mathrm{g}$ of dry soil). Bottles were sealed with butyl rubber stoppers, and soils were incubated at $25^{\circ} \mathrm{C}$. After 2 and 4 hours a $0.5 \mathrm{~cm}^{3}$ sample of the internal atmosphere was analyzed by gas chromatography (see previous paragraph). SIR was calculated from the $\mathrm{CO}_{2}$ increase during the $4 \mathrm{~h}$ incubation period. The bottles were further processed as described for BR measurement [15].

\section{Determination of hydraulic conductivity}

Saturated hydraulic conductivity $\left(K_{\text {sat }}\right)$ was calculated based on the measured volume of water that infiltrated into the soil (infiltration). Cumulative infiltration was measured using Mini-Disk Infiltrometer (MDI) according to Robichaud et al [16]. The measurement is based on the recording of the infiltrated volume of water over the time. High soil hydrophobicity slows water infiltration (hydraulic conductivity is lower) and conversely. Therefore, $K_{\text {sat }}$ may indicate a degree of soil hydrophobicity. This was confirmed also by Robichaud et al, Doerr et al, and Buczko et al [16-18].

The calculation of $K_{\text {sat }}$ was performed by Šindelár et al, Lichner et al, and Lichner et al [19-21]. $K_{\text {sat }}$ was calculated by the modified formula (1), originally Zhang [22]:

$$
K_{\text {sat }}=C_{2} / A_{2}
$$

where $C_{2}\left[\mathrm{~m} \cdot \mathrm{s}^{-1}\right]$ is the function of the soil water content $\theta$ and suction $\left(h_{0}\right)[\mathrm{cm}], A_{2}$ is dimensionless coefficient.

This parameter was determined by Van Genuchten equations, which were described by Zhang [22].

\section{Statistical analysis}

Differences in the amount of leached mineral nitrogen, index of nitrogen availability, respiration and hydraulic conductivity were analyzed by one-way analysis of variance 
(ANOVA) in combination with the Tukey's test. All analyses were performed using Statistica 10 software.

\section{Results and discussion}

\section{Leaching of mineral nitrogen}

Leaching of mineral nitrogen from arable soils is a major threat for the quality of drinking water from underground sources in the Czech Republic. The most dangerous are nitrates. These compounds are very mobile in the soil as they have a negative charge, whereas soil sorption complex has minimal affinity for negatively charged particles.

Figure 3 indicates significant differences in the leaching of $\mathrm{N}_{\min }$ in particular variants. The highest detection of $\mathrm{N}_{\min }\left(\mathrm{V} 3=78.42 \mathrm{mg} \cdot \mathrm{m}^{-2}\right)$ was recorded for the variant without $\mathrm{C}_{\text {org }}$ addition. Conversely, the lowest detection of $\mathrm{N}_{\min }\left(\mathrm{V} 4=37.19 \mathrm{mg} \cdot \mathrm{m}^{-2}\right)$ was found in variant with $\mathrm{C}_{\mathrm{p}}$ addition in comparison with control, reclamation substrate and the variant, where mineral nitrogen was applied. Increased value of $\mathrm{N}_{\min }$ losses in variant $\mathrm{V} 2$ was caused by a high dose of compost (12 fold higher dose in comparison with recommended dose). The values of $\mathrm{N}_{\min }$ in variant V4 indicate a positive effect of $\mathrm{C}_{\mathrm{p}}$ addition on leaching from arable soil. Diaz et al [9] state that during the production of compost microbial activity is developing and this activity continues after the application of compost. Moreover, according to Schimel and Bennett [23] microbial activities in soil are necessary for the utilization of nitrogen in soil.

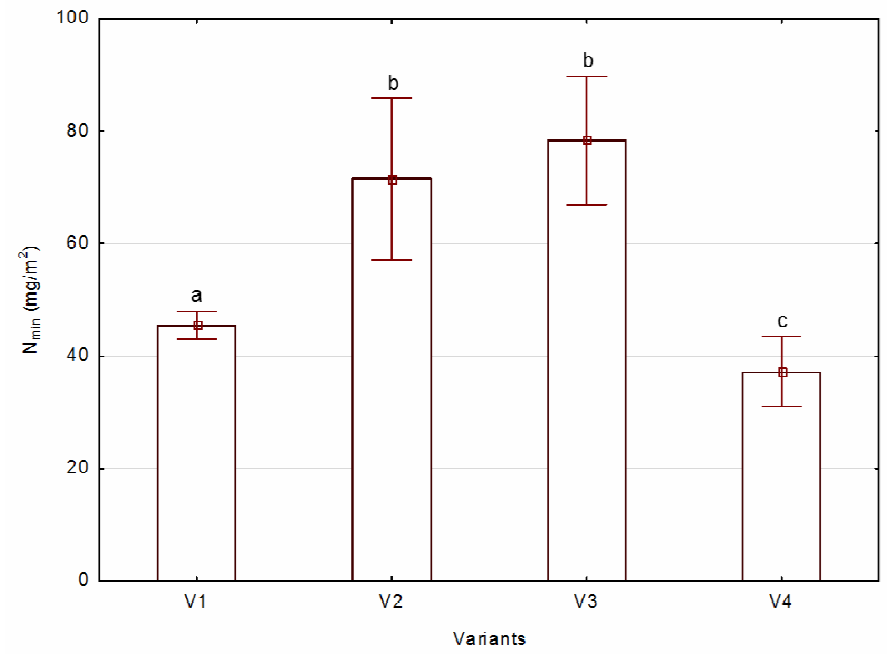

Fig. 3. Detection of mineral nitrogen (mean values \pm standard error, $n=4$, different letters indicate a significant differences at the level 0.05 - ANOVA, $P<0.05$ )

The compost addition has a positive effect on the leaching of $\mathrm{N}_{\min }$, because it contains carbon and two forms of nitrogen (mineral and organic). Carbon is a source of energy for microbial activities and nitrogen is the cornerstone for the construction of their bodies. More than $85-90 \%$ of total nitrogen is in organic form and is therefore immobile in soil and 
can be slowly degraded by soil microorganisms. This results in increased functionality of organic-mineral sorption complex and thus in increased capacity for the retention of soil environment for mineral nitrogen [4, 9, 24].

Content of $\mathrm{N}_{\min }$ in soil samples

Table 1

\begin{tabular}{|c|c|c|c|}
\hline Variants & $\mathbf{N}_{\min }[\mathbf{m g} / \mathbf{k g}]$ & $\mathbf{\pm S E}$ & Mean differences \\
\hline V1 & 20.40 & 1.58 & $\mathrm{a}, \mathrm{b}$ \\
\hline $\mathrm{V} 2$ & 21.56 & 0.82 & $\mathrm{a}, \mathrm{b}$ \\
\hline $\mathrm{V} 3$ & 17.46 & 2.01 & $\mathrm{a}$ \\
\hline $\mathrm{V} 4$ & 27.84 & 2.44 & $\mathrm{~b}$ \\
\hline
\end{tabular}

Mean values $\pm \mathrm{SE}$ (standard error), $n=4$. Different letters indicate a significant differences at the level 0.05 ANOVA $P<0.05$

The amount of mineral nitrogen in arable soil that was determined according to Bundy and Meisinger [14] is an important indicator of soil fertility. For complete results of $\mathrm{N}_{\text {min }}$ content see Table 2. The Table shows how values of $\mathrm{N}_{\min }$ content increase in variants with the addition of $\mathrm{C}_{\mathrm{p}}$ (V2 and V3). The stockpile of $\mathrm{N}_{\min }$ was larger in variant V4 compared to V3.

Data presented in Table 1 indicated positive effect of $\mathrm{C}_{\mathrm{p}}$ application on soil fertility content of nutrients $\left(\mathrm{N}_{\min }\right.$ - consisting of $\mathrm{NO}_{3}{ }^{-}-\mathrm{N}$ and $\left.\mathrm{NH}_{4}{ }^{+}-\mathrm{N}\right)$ in soil. The highest content of $\mathrm{N}_{\text {min }}$ was recorded for variant V4 with recommended dose of $\mathrm{C}_{\mathrm{p}}$. Conversely, the lowest content of $\mathrm{N}_{\min }$ was measured in variants with $\mathrm{N}_{\min }$ addition. Nevens and Reheul, and Weber et al $[11,24]$ confirm that the application of $\mathrm{C}_{\mathrm{p}}$ contributes to an increase of $\mathrm{N}_{\min }$ content in soil, because $\mathrm{C}_{\mathrm{p}}$ contains organic matter, which is decomposed by soil microorganisms to $\mathrm{NH}_{4}{ }^{+} \mathrm{N}$ and subsequently to $\mathrm{NO}_{3}{ }^{-}-\mathrm{N}$. Moreover, $\mathrm{C}_{\mathrm{p}}$ contains carbon, so that microorganisms had sufficient source of energy for processing available organic nitrogen. Consider Figure 3 and Table 1, which show a relationship between values of $\mathrm{N}_{\min }$ leaching and values of $\mathrm{N}_{\min }$ content. These values confirm that recommended dose of $\mathrm{C}_{\mathrm{p}}$ has a positive effect on the increase of $\mathrm{N}_{\min }$ content and its retention in soil, which is a prerequisite for increasing soil fertility.

\section{Ammonium production during waterlogged incubation}

Ammonium $\mathrm{N}\left(\mathrm{NH}_{4}{ }^{+}-\mathrm{N}\right)$ production during waterlogged incubation indicates the amount of $\mathrm{NH}_{4}{ }^{+}-\mathrm{N}$ in microbial biomass, but does not indicate microbial activities in soil [14]. Amounts of $\mathrm{NH}_{4}{ }^{+}-\mathrm{N}$, which was released from microbial biomass, are summarized in Table 2. These data do not show significant differences among individual variants.

Index of nitrogen availability

\begin{tabular}{|c|c|c|c|}
\hline Variants & $\mathbf{N H}_{\mathbf{4}}{ }^{\mathbf{}}-\mathbf{N}[\mathbf{m g} / \mathbf{k g}]$ & $\mathbf{\pm S E}$ & Mean differences \\
\hline V1 & 35.13 & 2.19 & $\mathrm{a}$ \\
\hline V2 & 40.93 & 2.30 & $\mathrm{a}$ \\
\hline V3 & 32.81 & 2.59 & $\mathrm{a}$ \\
\hline V4 & 34.71 & 0.70 & $\mathrm{a}$ \\
\hline
\end{tabular}

Mean values $\pm \mathrm{SE}$ (standard error), $n=4$ 


\section{Basal and substrate indicated respiration}

According to previous researches, soil microorganism controls soil respiration and nitrogen mineralization [25]. Silva et al found that microbial and actinomycete populations were positively correlated with gross mineralization and ammonium consumption rates [26]. Muller et al used barometric process separation (BaPS) techniques to indicate that soil microorganism affected soil respiration [27]. Additionally, soil respiration and nitrogen mineralization are also influenced by many environmental factors including soil hydrology, soil texture, and soil aggregate [25]. Moreover, it is widely reported that soil temperature can significantly impact microbial species, quantity, and activity which determine these soil processes [25].

Soil respiration is one of the most important indicators of microbial activity in the soil $[15,28,29]$. Soil respiration is attributed to a wide range of microorganisms, such as fungi, bacteria, protozoa and algae. Moreover, the soil fauna contributes significantly. Generally, the microbial contribution to the total release of $\mathrm{CO}_{2}$ (excluding root respiration) is thought to be about $90 \%$, compared to $10 \%$ released by the fauna. Although fungal biomass often dominates microbial biomass the relation fungi vs. bacteria with respect to respiration may vary considerably, due to, for example, type of ecosystem or soil management. To complete the picture, plant roots also contribute between 12 and $30 \%$ to the total release of $\mathrm{CO}_{2}$ through respiration in the field [29]. The above stated confirm the importance of respiration for the assessment of soil quality.

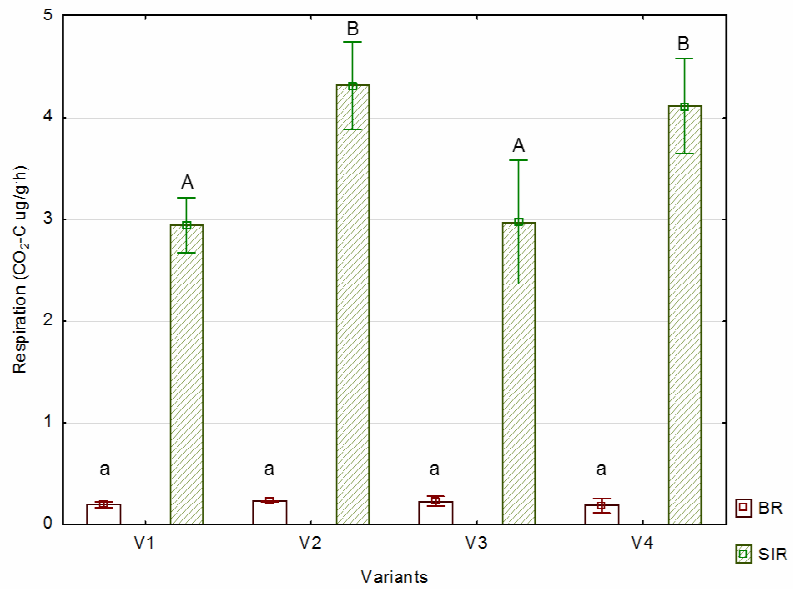

Fig. 4. Basal and substrate induced respiration (mean values \pm standard error, $n=4$, different letters indicate a significant differences at the level 0.05 - ANOVA, $P<0.05$ )

During the experiment, two types of respiration were measured: $B R$ and SIR. The values of both respirations are presented in Figure 5. Significant differences were found only in $S I R, B R$ was at the same level for all variants. This situation is not surprising because respiration was measured after the termination of the experiment, at a time when the activity reached its peak. According to Bloem et al [29] BR is the steady rate of respiration in soil, which originates from the turnover of organic matter. And SIR (method) 
is based on the detection of a respiratory response of soil microorganisms on supply of glucose. Thus, only glucose-responsive and active organisms are measured.

SIR is more important for the assessment of compost and mineral nitrogen addition on microbial activities and thus the soil properties. The highest values of SIR were found in variants V2 $(4.31 \mu \mathrm{g} / \mathrm{g} \cdot \mathrm{h})$ and V4 $(4.11 \mu \mathrm{g} / \mathrm{g} \cdot \mathrm{h})$. Conversely, the lowest values were detected in variants without compost $(\mathrm{V} 1, \mathrm{~V} 2)$. These data indicated that the addition of $\mathrm{C}_{\mathrm{p}}$ has a positive effect on soil quality. Borken et al [28] confirmed that the application of compost has a positive effect on SIR and thus on microbial activities.

Small letters indicate a significant difference $(P<0.05)$ among individual variants in BR and different uppercase letters indicate a significant difference $(P<0.05)$ among individual variants in SIR.

\section{Plant biomass production}

After 63 days, on $28^{\text {th }}$ April 2014, indicator plant was harvested and it production is the main indicator of compost and mineral nitrogen addition on plant production for individual variants. Production of aboveground and underground biomass is presented in Figure 6. Significant differences were found only in production of aboveground biomass $(A B)$. The highest production of $A B$ was found in variant V1 $(P<0.05)$ and the lowest production of $A B$ was detected in variant $\mathrm{V} 3$. In addition, the production of $\mathrm{AB}$ was lower than the production in $\mathrm{V} 1$, but higher than in $\mathrm{V} 3$.

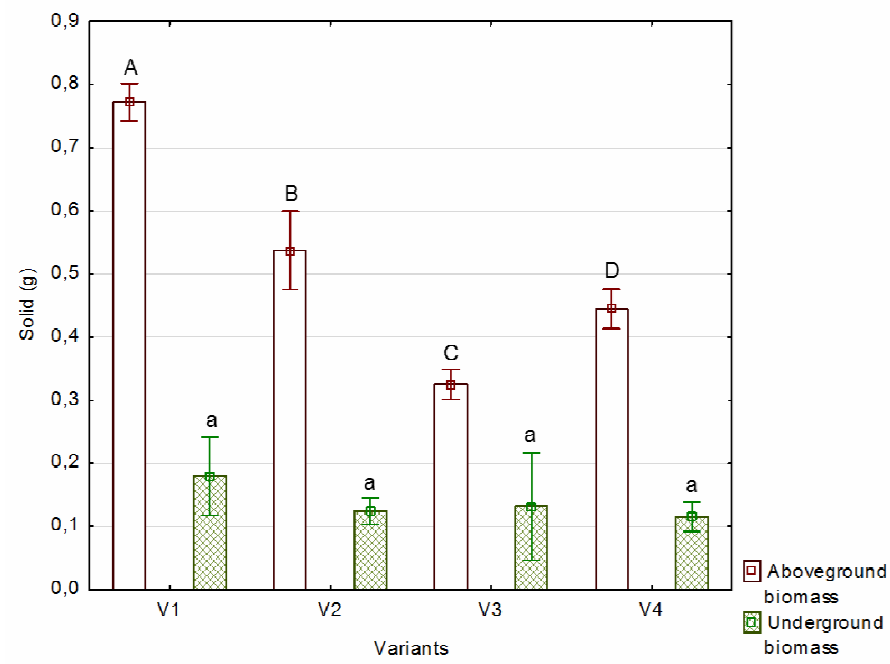

Fig. 5. Production of plant biomass (mean values \pm standard error, $n=4$, different letters indicate a significant differences in production of above and underground biomass among individual variants at the level $0.05-$ ANOVA, $P<0.05$ )

These results indicate that the application of $\mathrm{C}_{\mathrm{p}}$ had a greater effect on plant growth than the application of mineral nitrogen, which was applied in variant V3. The significant differences between control variant and variants with the addition of compost could be due to phytotoxicity or worse quality of $\mathrm{C}_{\mathrm{p}}$. Aslam et al, Tiquia and Himanen and Hänninen 
[30-32] draw attention to the danger of phytotoxicity of compost, which can be caused by raw input, a mistake in the manufacturing process or its excessive applications. Increasing the dose of $\mathrm{C}_{\mathrm{p}}$ could cause phytotoxicity of reclamation substrate and thus reduced production of $A B$. Conversely, recommended dose of $\mathrm{C}_{\mathrm{p}}$ was applied in variant $\mathrm{V} 4$ and this type of $\mathrm{C}_{\mathrm{p}}$ (Black Dragon) had already been successfully tested [10, 12, 33] and each time its positive effects on plant biomass production have been demonstrated. There is a presumption that the sample taken of $\mathrm{C}_{\mathrm{p}}$ contained fewer nutrients than samples used in previous experiments. Despite this fact, this type of $\mathrm{C}_{\mathrm{p}}$ applied in V3 had a positive effect on soil fertility in comparison with other variants. The highest values of SIR, content of $\mathrm{N}_{\text {min }}$ in soil and the lowest value of leaching of $\mathrm{N}_{\min }$ were found here.

Different uppercase letters indicate a significant difference $(P<0.05)$ among individual variants in production of aboveground biomass and different small letters indicate a significant difference $(P<0.05)$ among individual variants in underground biomass.

\section{Hydraulic conductivity}

Soil water repellency is a widespread phenomenon, which affects infiltration as well as soil water retention and plant growth. It can be responsible for enhanced surface runoff, erosion and preferential flow. Due to this high relevance, a great number of studies have been conducted on possible causes of water repellency and point to a variety of factors causing and influencing repellency $[16,17]$.

Doerr et al, Buczko et al, and Robichaud et al [16-18] confirmed that soil hydrophobicity has direct impact on water infiltration into soil. The ability of the soil to accept water can be expressed as (saturated) hydraulic conductivity $K_{\text {sat }}$. Therefore, $K_{\text {sat }}$ may be used to determine the degree of hydrophobicity of the soil.

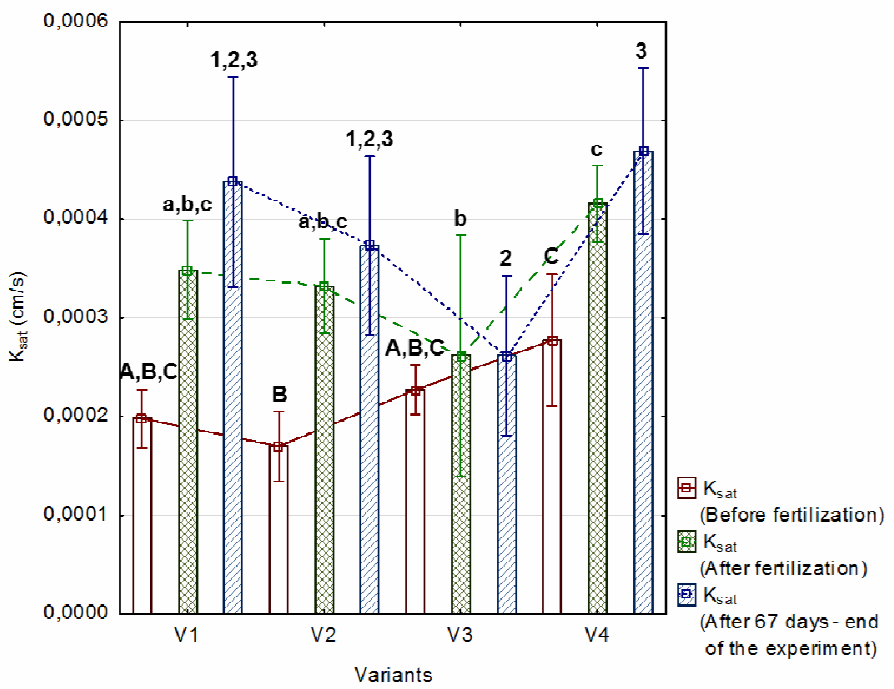

Fig. 6. Impact of compost addition and mineral nitrogen application on saturated hydraulic conductivity (mean values \pm standard error, $n=4$, different letters indicate a significant differences in $K_{\text {sat }}$ among individual variants at the level 0.05 - ANOVA, $P<0.05$ ) 
The values of $K_{\text {sat }}$ were calculated based on the measured volume of water (cumulative infiltration) which were measured in three periods: (a) before the application of mineral fertilizer into variant V3 (12 days after the establishment of the experiment), (b) after the application of mineral fertilizer (34 days after the establishment of the experiment) and (c) at the end of the experiment (63 days following the establishment of the experiment). Figure 6 displays the values of $K_{s a t}$ for three periods. In each period, the highest values of $K_{\text {sat }}$ were found in variant V4. Furthermore, these values were significantly $(P<0.05)$ higher than values in variant $\mathrm{V} 3$ (addition of $\mathrm{N}_{\min }$ ) in the last two periods. This fact is very important for the authors because it confirms the premise that the application of $\mathrm{C}_{\text {org }}$ has a positive effect on soil hydrophobicity and soil properties in terms of a longer period of time, but the authors stress that the experiment was conducted in specific conditions and it should be repeated as a field and laboratory experiment. Considering values of $K_{\text {sat }}$ in variant V2 (the application of reclamation substrate), these values were higher than values in variant V3, but these differences are insignificant.

Diaz et al, Walker and Bernal, and Lakhdar et al [9, 34, 35] confirm a positive effect of compost addition on the development of soil biota and on physical and chemical properties of soil. Therefore, the application of $\mathrm{C}_{\mathrm{p}}$ had an influence on leaching of mineral nitrogen and the values of hydraulic conductivity.

Different uppercase letters indicate a significant difference $(P<0.05)$ among individual variants in the first period, different small letters indicate a significant difference among individual variants in the second period and different numbers indicate a significant difference among individual variants in the third period.

\section{Conclusions}

Our experiment showed the potential benefits of compost and reclamation substrates application. Based on these results, we can conclude the addition of compost (separately or as reclamation substrate) has a positive effect on microbial activity and decrease leaching of mineral nitrogen from the soil. Moreover, the content of compost (organic matter) has directly affected soil hydrophobicity, which is very important for stability of soil aggregates. For these comparisons, we may draw the following conclusions. There are great differences between arable soils with addition of compost and arable soils without, as it was expected. Compost has a positive impact on the soil environment and thus on soil properties: content of organic matter in soil, soil fertility, microbial activities etc. This positive effect is manifested in all variants of experiment where compost was applied. The authors are aware that the experiment was conducted under laboratory conditions and it should be repeated as a field-experiment.

\section{Acknowledgments}

This study was supported by the IGA - Internal Grant Agency Faculty of Agronomy MENDELU No. IP 19/2014. And this work was supported by the National Agency for Agricultural research (NAZV), project: The possibilities for retention of reactive nitrogen from agriculture in the most vulnerable infiltration area of water resources, registration no. QJ 122007. 


\section{References}

[1] Różański S. Fractionation of selected heavy metals in agricultural soils. Ecol Chem Eng S. 2013;20(1):117-125. DOI: 10.2478/eces-2013-0009.

[2] Lang A, Bork HR. Past soil erosion in Europe. Boardman J, Poesen J, editors. Soil Erosion in Europe. Chichester: John Wiley \& Sons; 2006:465-476. DOI: 10.1002/0470859202.

[3] Świtonia M. Use of soil profile truncation to estimate influence of accelerated erosion on soil cover transformation in young morainic landscapes, North-Eastern Poland. CATENA. 2014;116:173-184. DOI: 10.1016/j.catena.2013.12.015.

[4] Wolf B, Snyder GH. Sustainable Soils. The Place of Organic Matter in Sustaining Soils and their Productivity. Food Products Press. Binghamton; 2003.

[5] Abdollahi L, Schjonning P, Elmholt S, Munkholm LJ. The effects of organic matter application and intensive tillage and traffic on soil structure formation and stability. Soil Till Res. 2014;136:28-37. DOI: 10.1016/j.bbr.2011.03.031

[6] Halberg N, Alrøe HF, Knudsen MT, Kristensen ES, editors. Global Development of Organic Agriculture. Challenges and Prospects. Wallingford: CABI Publishing; 2006.

[7] Slavík R, JulinovÁ M, Labudíková M. Screening of the spatial distribution of risk metals in topsoil from an industrial complex. Ecol Chem Eng S. 2012;19(2):259-272. DOI: 10.2478/v10216-011-0020-0.

[8] Bissonnais YL, Montier C, Jamagne M, Daroussin J, King D. Mapping erosion risk for cultivated soil in France. CATENA. 2002;46(2-3):207-220. DOI: 10.1016/S0341-8162(01)00167-9.

[9] Diaz LF, Bertoldi M, Bidlingmaier W, Stentiford E. Compost Science and Technology. Amsterdam: MA Elsevier; 2007.

[10] Plošek L, Nsanganwimana F, Pourrut B, Elbl J, Hynšt J, Kintl A, et al. The effect of compost addition on chemical and nitrogen characteristics, respiration activity and biomass production in prepared reclamation substrates. Int J Agri Scien Eng. 2013;7:363-369.

[11] Nevens F, Reheul D. The application of vegetable, fruit and garden waste (VFG) compost in addition to cattle slurry in a silage maize monoculture: nitrogen availability and use. Eur J Agron. 2003;19:189-203. DOI: $10.1016 / \mathrm{S} 1161-0301(02) 00036-9$.

[12] Elbl J, Plošek L, Kintl A, Přichystalová J, Záhora J, Hynšt J. Effect of organic-waste compost addition on leaching of mineral nitrogen from arable land and plant production. World Academy of Science, Engineering and Technology. 2013;7:2066-2072.

[13] Peoples MB, Faizah AW, Rerkasem B, Herridge DF. Methods for Evaluating Nitrogen Fixation by Nodulated Legumes in the Field. Canberra: Australian Centre for International Agricultural Research; 1989.

[14] Bundy LG, Meisinger JJ. Nitrogen Availability Indices - Methods of Soil Analysis, Part 2. Microbiological and biochemical properties. SSA Book Series; 1994.

[15] Šimek M, Virtanen S, Krištůfek V, Simojoki A, Yli-Halla M. Evidence of rich microbial communities in the subsoil of boreal acid sulphate soil conductive to greenhouse gas emissions. Agric Ecosyst Environ. 2011;140:113-122. DOI: 10.1016/j.agee.2010.11.018.

[16] Robichaud PR, Lewis SA, Ashmun LE. New Procedure for Sampling Infiltration to Assess Post-fire Soil Water Repellency. Res. Note. RMRS-RN-33. Rocky Mountain Station U.S.: Department of Agriculture, Forest Service; 2008.

[17] Doerr SH, Shakesby RA, Walsh RPD. Soil water repellency: its causes, characteristics and hydro-geomorphological significance. Earth-Sci Rev. 200;51:35-65. DOI: 10.1016/S0012-8252(00)00011-8.

[18] Buczko U, Bens O, Hüttl RF. Variability of soil water repellency in sandy forest soils with different stand structure under Scots pine (Pinus sylvestris) and beech (Fagus sylvatica). Geoderma. 2005;126:317-336. DOI: 10.1016/j.geoderma.2004.10.003.

[19] Šindelář R, Kovaříček P, Vlášková M, Hůla J, Krouhlík M. Measurement of water infiltration into soil using round infiltrometer mini disk. Agritech Science. 2008;2:1-6.

[20] Lichner L, Hallett P, Feeney DS, Ďugová O, Šír M, Tesař M. Field measurement of soil water repellency and its impact on water flow under different vegetation. Biologia (Section botany). 2007;62:537-541.

[21] Lichner L, Orfánus T, Nováková K, Šír M, Tesař M. The impact of vegetation on hydraulic conductivity of sandy soil. Soil \& Water Res. 2007;2:59-66.

[22] Zhang R. Determination of soil sorptivity and hydraulic conductivity from the disk infiltrometer. Soil Sci Soc Am J. 1997;22:621-626. DOI: 10.2136/sssaj1997.03615995006100040005x.

[23] Schimel JP, Bennett J. Nitrogen mineralization: challenges of a changing paradigm. Ecology. 2004;85:591-602. 
[24] Weber J, Karcyewska A, Drozd J, Licznar M, Jamroz E, Kocowicz A. Agricultural and ecological aspects of a sandy soil as affected by the application of municipal solid waste compost. Soil Biol Biochem. 2007;39:1294-1302. DOI: 10.1016/j.soilbio.2006.12.005.

[25] Wen-Zhi Z, Chi X, Jing-Wei W, Jie-Sheng H, Tao M. Effect of salinity on soil respiration and nitrogen dynamics. Ecol Chem Eng S. 2013;20(3):519-530. DOI: 10.2478/eces-2013-0039.

[26] Silva RG, Jorgensen EE, Holub SM, Gonsoulin ME. Relationships between culturable soil microbial populations and gross nitrogen transformation processes in a clay loam soil across ecosystems. Nutr Cycl Agroecos. 2005;71(3):259-270. DOI: 10.1007/s10705-004-6378-y.

[27] Muller C, Abbasi MK, Kammann C, Clough TJ, Sherlock RR, Stevens RJ, et al. Soil respiratory quotient determined via barometric process separation combined with nitrogen-15 labeling. Soil Sci Soc Am J. 2004;68(5):1610-1615.

[28] Borken W, Muhs A, Beese F. Aplication of compost in spruce forest: effect on soil respiration, basal respiration and microbial biomass. Forest Ecol Manag. 2002;159: 49-58. DOI: 10.1016/S0378-1127(01)00709-5.

[29] Bloem J, Hopkins DW, Benedetti A. Microbiological Methods for Assessing Soil Quality. Wallingford: CABI Publishing; 2006.

[30] Aslam DN, Horwath W, Vander Gheynst JS. Comparison of several maturity indicators for estimating phytotoxicity in compost-amended soil. Waste Manage. 2008;28:2070-2076. DOI: 10.1016/j.wasman.2007.08.026.

[31] Tiquia SM. Reduction of compost phytotoxicity during the process of decomposition. Chemosphere. 2010;79:506-512. DOI:10.1016/j.chemosphere.2010.02.040.

[32] Himanen M, Hänninen K. Composting of bio-waste, aerobic and anaerobic sludges - effect of feedstock on the process and quality of compost. Biores Technol. 2011;102:2842-2852. DOI: 10.1016/j.biortech.2010.10.059.

[33] Elbl J, Plošek L, Záhora J, Kintl A, Stroblová M. Effect of increased doses of compost to prepare reclamation substrate on soil respiration and content of mineral nitrogen in the soil. Ad Alta. 2013;3:88-91.

[34] Walker DJ, Bernal MP. The effects of olive mill waste compost and poultry manure on the availability and plant uptake of nutrients in a highly saline soil. Biores Technol. 2008;99:396-403. DOI: 10.1016/j.biortech.2006.12.006.

[35] Lakhdar A, Rabhi M, Ghaya T, Montemurro F, Jedidi N, Abdelly Ch. Effectiveness of compost use in salt-affected soil. J Hazardous Mater. 2009;171:29-37. DOI: 10.1016/j.jhazmat.2009.05.132.

[36] Schaumann GE, Braun B, Kirchner D, Rotard W, Szewzyk U, Grohmann E. Influence of biofilms on the water repellency of urban soil samples. Hydrological Processes. 2007;21:2276-2284. DOI: 0.1002/hyp.6746.

\title{
WPŁYW NAWOŻENIA NA AKTYWNOŚĆ MIKROORGANIZMÓW, HYDROFOBOWOŚĆ GLEBY ORAZ WYPLUKIWANIE AZOTU MINERALNEGO
}

\author{
${ }^{1}$ Zakład Agrochemii, Gleboznawstwa, Wydział Mikrobiologii i Żywienia \\ Wydział Rolniczy, Uniwersytet Mendla w Brnie, Czechy \\ ${ }^{2}$ Zakład Zastosowań i Ekologii Krajobrazu, Wydział Rolniczy, Uniwersytet Mendla w Brnie, Czechy
}

\begin{abstract}
Abstrakt: W pracy przedstawiono analizę wpływu kompostu, substratu rekultywacyjnego oraz zastosowanie nawozów mineralnych na wymywanie azotu mineralnego, działalności mikroorganizmów, hydrofobowość gleby i produkcję biomasy roślinnej. W celu zbadania efektu wykorzystania kompostu, substratu rekultywacyjnego oraz azotu mineralnego $\left(\mathrm{N}_{\min }\right)$ został przeprowadzony eksperyment $\mathrm{w}$ doniczkach. Jako modelowa roślina została wykorzystana Deschampsia caespitosa L, którą hodowano przez 63 dni w komorze klimatycznej. Wymywanie $\mathrm{N}_{\min }$ zostało zmierzone przy zastosowaniu tarcz jonowymiennych, hydrofobowość gleby określono na podstawie wartości przewodnictwa nasyconego hydraulicznego $\left(K_{\text {sat }}\right)$, a aktywność mikrobiologiczną wyrażono jako podstawową $(B R)$ oraz wskaźnik oddychania podłoża $(S I R)$. Wykorzystano cztery próbki (V1-V4) o różnych dawkach nawozów: V1 - kontrola bez dodatku nawozu, V2 - mieszanka kompostu oraz gleby w stosunku 7:3, $\mathrm{V} 3-90 \mathrm{~g} / \mathrm{m}^{2}$ nawozu mineralnego NPK (w stosunku 1:1:1) oraz V4 - dawka $30 \mathrm{~g}$ kompostu. Stwierdzono znaczne różnice $(P<0,05)$ w badaniu $\mathrm{N}_{\min }$, wartości $K_{\text {sat }}$ oraz $S I R$. Największy ubytek azotu mineralnego zaobserwowano podczas jednoczesnej aplikacji kompostu (V4) do gleby uprawnej, około $50 \%$ w porównaniu z próbką V4 (zastosowanie nawożenia mineralnego) i około $10 \%$ w porównaniu z kontrolą. Próbki z dodatkiem kompostu (V2 i V4) wykazywały wyższe wartości niż próbki bez kompostu, co zostało zmierzone w trzech
\end{abstract}


etapach (przed zastosowaniem $\mathrm{N}_{\min }-12$ dni po rozpoczęciu eksperymentu, po zastosowaniu $\mathrm{N}_{\min }-34$ dni oraz na koniec eksperymentu - 63 dni). Podczas eksperymentu respiracja była mierzona: BR oraz SIR. Wyraźne różnice w SIR zostały zaobserwowane pomiędzy próbkami z dodatkiem kompostu oraz próbkami bez dodatku kompostu. SIR (skumulowana produkcja $\mathrm{CO}_{2}$ ) była wyższa o około $25 \%$ w próbkach V2 oraz V4 w porównaniu z próbkami V1 oraz V3. Najwyższe wartości $K_{\text {sat }}$ zaobserwowano w przypadku próbek z dodatkiem kompostu. Wartość najniższą $K_{\text {sat }}$ zaobserwowano dla próbek bez dodatku $\mathrm{N}_{\text {min }}$. Niskie wartości $K_{\text {sat }}$ wykazują zwiększony poziom hydrofobowości.

Słowa kluczowe: kompost, substrat rekultywacyjny, działalności mikroorganizmów, azot mineralny, hydrofobowość gleby 